Journal of Nepal Geological Society, 2019, vol. 59, pp. 39-48

DOI: https://doi.org/103126/jngs.v59i0.24984

\title{
Towards effective and sustainable disaster risk management in Nepal: challenges and gaps
}

\author{
Ramesh Man Tuladhar \\ National Disaster Risk Reduction Coordination Subcommittee, Nepal Geological Society \\ Email: r.tula1950@gmail.com
}

\begin{abstract}
Geo-hazards, dynamic Himalayan tectonics, high seismicity, predominant soft rock (argillaceous) formations, steep slopes, rugged (high elevation difference) terrain, when mistreated would trigger-disasters. These natural factors exacerbated by unplanned developments together with impacts of global climate change have further scaled-up disasters in Nepal. Common natural disasters in Nepal impacting the livelihoods of the people below poverty are: earthquakes, floods and landslides. The return period of former is longer (+/- 70 years) but catastrophic, e.g. Gorkha-earthquake, while latter ones are recurrent and chaotic.

Substantial efforts have been made on disaster risk reductions (DRR) both by the state and non-state organizations. Contributions from sectoral ministries led by the Ministry of Home Affairs are primarily focused to legal provisions, strategies and policies while the departments are mandated to implement sectoral activities through projects and programs. Post Gorkha-earthquake rescue and relief operations demonstrated an exemplary solidarity among national, bilateral and international organizations. Reconstruction works are rather slow and still being continued. Despite substantial DRR efforts, outcomes are not satisfactory to the desired extent, whether it is earthquake or are floods and landslides across the country as per media and public voices reported.

This paper aims to analyse some key questions towards effective and sustainable disaster risk management in Nepal against existing challenges and gaps in the backdrop of Sendai Framework for Disaster Risk Reduction (SFDRR) 2015-2030. A theory of change that would help improve effectiveness and sustainability of disaster risk management (DRM) in Nepal is envisioned and discussed.
\end{abstract}

Keywords: Disaster risk reduction, Sendai framework, effectiveness, indicator, sustainability

Paper Received: 24 Jan 2019

Paper Accepted: 4 May 2019

\section{INTRODUCTION}

Nepal is exposed to multiple geo-hazards. Notable ones include high seismicity due to dynamic Himalayan tectonics, predominance of soft rock (argillaceous formation) exposures, steep slopes, ruggedness (high elevation difference) of terrain. Due to unplanned rampant development activities across the country new hazards are created at faster rate such as degradation of land, desertification of Churia hills, depletion of water resources, rise of bed level in the rivers among others. These are leading to manifestations of recurrent disaster events.

It is alarming to note these newly created natural geohazards which otherwise could have substantially reduced through implementation of systematic disaster management framework such as Sendai Framework for Disaster Risk Reduction (SFDRR) 2015-2030 (UNISDR, 2015). Substantial efforts have been made on DRR during the HFA era (2005-2015) both by the state and non-state organizations and continue to do so. But how effective and sustainable are the efforts is the key questions and essential to review them in the backdrop of SFDRR.

The primary aim of the paper is to access and review efforts made by the state organizations towards effective and sustainable DRM in Nepal against prevailing challenges and gaps. The Sendai Framework for Disaster Risk Reduction 2015-2030, an outcome of 3rd World Conference on DRR, complimented by SDGs provides an opportunity to improve overall DRR scenario in Nepal through learning from HFA implementation in Nepal. A theory of change aimed at improving the effectiveness and sustainability of DRM through systematic monitoring and evaluation of the key activities identified by the Government of Nepal and UNDP under 4 Priority of Action of SFDRR has been envisioned.

\section{PROGRESS REVIEW OF HFA 2005-2015}

Substantial efforts during HFA period (2005-15) have been made on disaster risk reductions (DRR) both by the state and non-state organizations. Contributions from sectoral ministries lead by the Ministry of Home Affairs, which is the nodal ministry for DRR in Nepal, had lead initiatives that engages a range of stakeholders from ministries to departments to UN organizations to I/NGOs to development partners and private sectors. Nepal has made significant progress in prioritizing DRR through promotional development of policy, strategies and plans despite numerous challenges and gaps.

However, desired outcomes and impacts of DRR 
interventions are far from achieving the HFA goals. Many policy decisions and strategic action plans could merely be implemented. Institutional arrangements and several committees formed for DRR remained moderately effective. Major reasons pointed out by key actors namely Dept. of Mines and Geology, Dept. of Hydrology and Meteorology, Dept. of Soil Conservation and Watershed Management, Dept. of Water Induced Disaster Management and Dept. of Irrigations among others (organizational members of DP Net Nepal) are none other than lack of fundamental requirements e.g. financial resources and human resources with desired knowledge and capacity among others. Other crucial drawback is the chronic none cooperative negative attitudes of beneficiaries towards implementers. While majority of beneficiaries do have high demands on structural mitigation measures but found not ready to contribute to operation and maintenance works (both in-kind or in-cash). Despite these issues, substantial progress was made in all five priorities for actions of HFA. In terms of performance, effectiveness and sustainability, it was found to be moderately satisfactory. An effort has been made for a quantitative analysis of available information of all five priority of action based on the underlying Score Card and graphically illustrated (Figs. 1 to 5). below:

Level of progress has been classified into 3 scales as

\section{Scale of Performance Ranking}

1. Minor progress with few signs of forward action in plans or policy

2. Some progress, but without systematic policy and/or institutional commitment

3. Institutional commitment attained, but achievements are neither comprehensive nor substantial

4. Substantial achievement attained but with recognized limitations in capacities and resources

5. Comprehensive achievement with sustained commitment and capacities at all levels

\section{Scale of Effectiveness}

1. Ineffective (I)

2. Moderately Ineffective (MI)

3. Moderately Effective (ME)

4. Effective (E)

5. Highly Effective (HE)

\section{Scale of Sustainability}

1. Unsustainable (U)

2. Moderately Unsustainable (MU)

3. Moderately Sustainable (MS)

4. Sustainable (S)

5. Highly Sustainable (HS)

\section{Priority for Action 1:}

It ensure that disaster risk reduction are national and local priorities with a strong institutional basis for implementation (Table 1).

Core Indicator 1: National policy and legal framework for disaster risk reduction exist with decentralized responsibilities and capacities at all levels Core Indicator 2: Dedicated and adequate resources are available to implement disaster risk reduction plans and activities at all administrative levels

Core Indicator 3: Community Participation and decentralization is ensured through the delegation of authority and resources to local levels

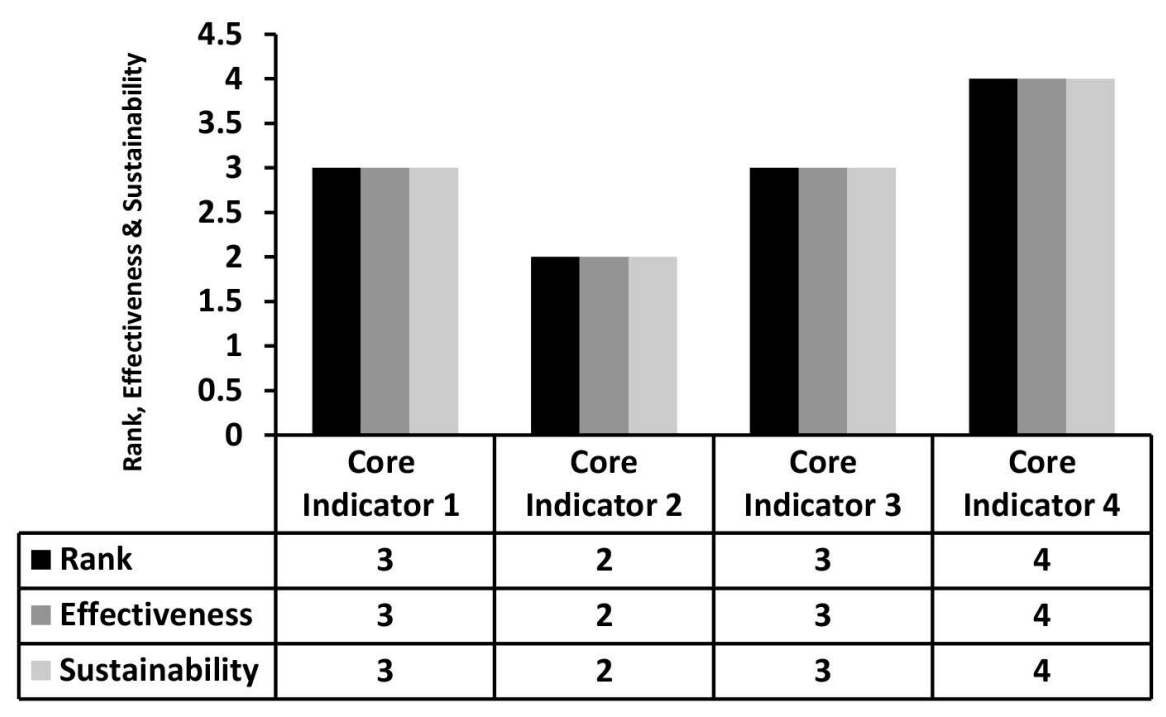

Fig. 1: Status of HFA Priority of Action 1 


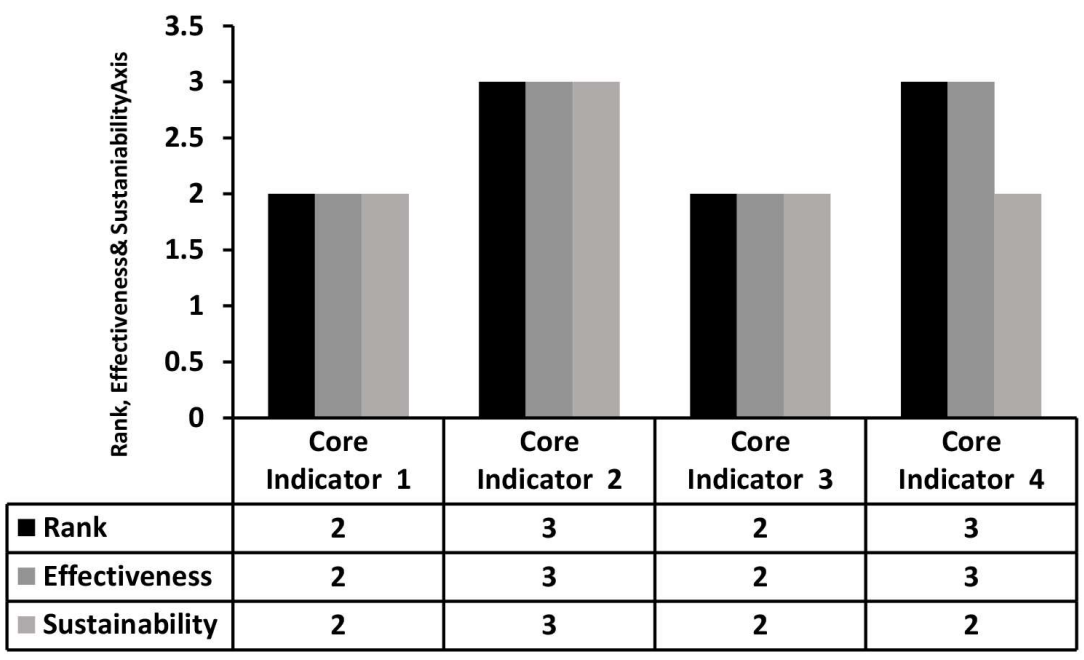

Fig. 2: Status of HFA Priority of Action 2

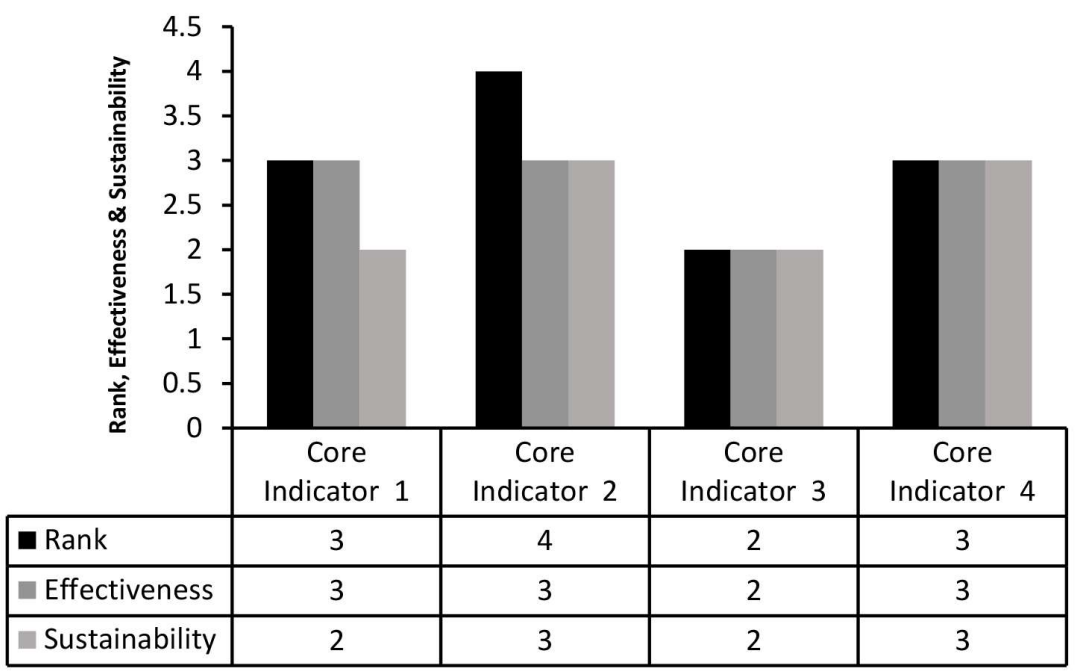

Fig. 3: Status of HFA Priority of Action 3

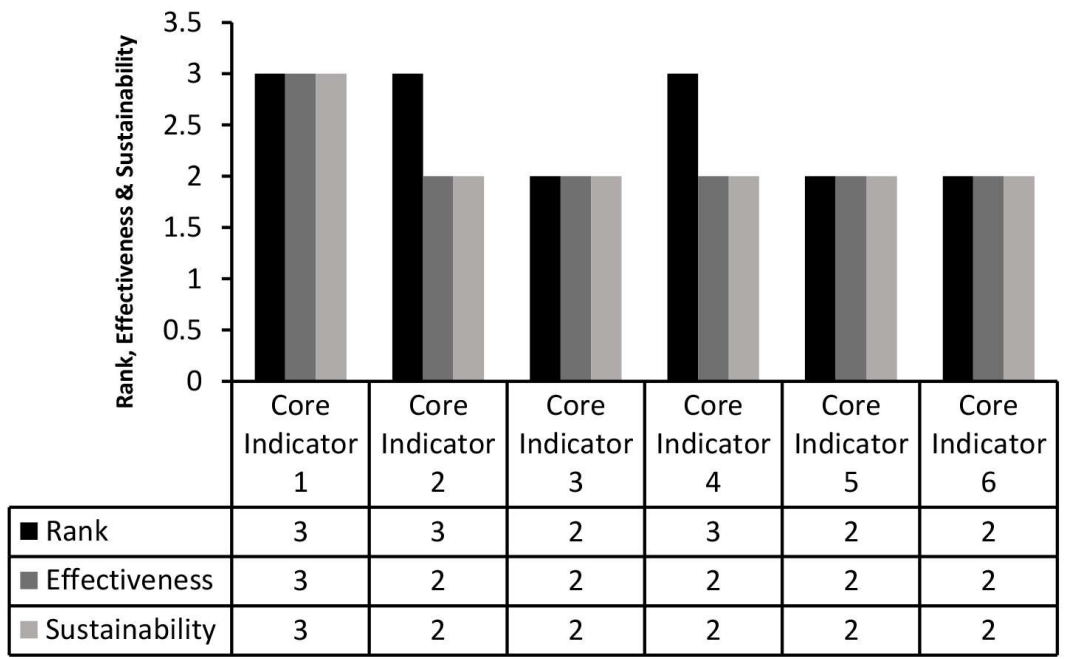

Fig. 4: Status of HFA Priority of Action 4 


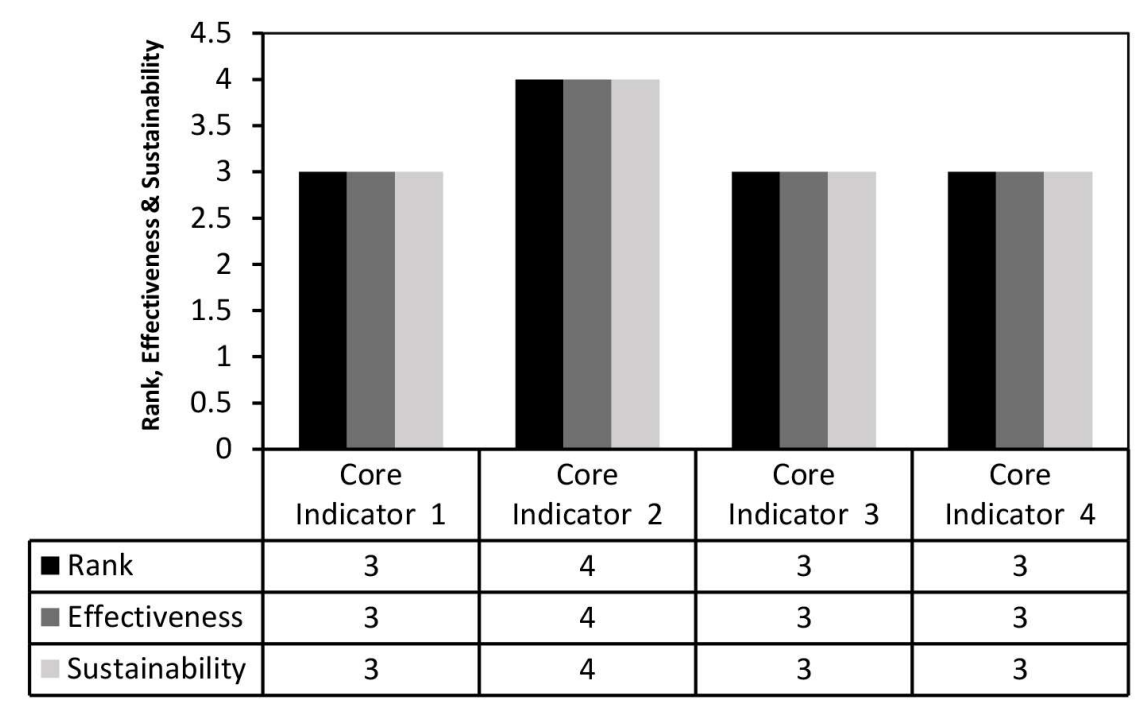

Fig. 5: Status of HFA Priority of Action 5

Table1: SFDRR Priority of Action 1- Understanding Disaster Risk (UNISDR, 2015)

\begin{tabular}{|c|c|c|c|c|}
\hline Activity & Instrument & Indicator & $\begin{array}{l}\text { Unit of } \\
\text { Measure }\end{array}$ & Anticipated Outcome \\
\hline $\begin{array}{l}\text { 1. Hazard wise } \\
\text { Assessment of Disaster } \\
\text { Risks }\end{array}$ & $\begin{array}{l}\text { Conduct assessment of } \\
\text { disaster- prone specific } \\
\text { hazards }\end{array}$ & $\begin{array}{l}\text { Increased nos. assessment } \\
\text { of disaster-prone specific } \\
\text { hazards }\end{array}$ & Number & $\begin{array}{l}\text { Understanding of disaster- } \\
\text { prone specific hazards better }\end{array}$ \\
\hline $\begin{array}{l}\text { 2. Interagency } \\
\text { Coordination for Multi- } \\
\text { Hazard Risk Assessment }\end{array}$ & $\begin{array}{l}\text { Conduct Multi-Hazard } \\
\text { Risk Assessment through } \\
\text { Interagency Coordination } \\
\text { facilitated by DP Net }\end{array}$ & $\begin{array}{l}\text { Increased nos. Multi- } \\
\text { Hazard Risk assessment }\end{array}$ & Number & $\begin{array}{l}\text { Understanding of Multi- } \\
\text { Hazard Risk better }\end{array}$ \\
\hline $\begin{array}{l}\text { 3. Effective } \\
\text { Dissemination and } \\
\text { Sharing of Disaster Risk } \\
\text { Information }\end{array}$ & $\begin{array}{l}\text { Develop an exclusive } \\
\text { web portal to } \\
\text { disseminate and share } \\
\text { realtime DR information }\end{array}$ & $\begin{array}{l}\text { Improved dissemination } \\
\text { and sharing of DR } \\
\text { information on or near } \\
\text { realtime }\end{array}$ & $\%$ & $\begin{array}{l}\text { Understanding of the DR } \\
\text { information on or near } \\
\text { realtime for better } \\
\text { preparedness }\end{array}$ \\
\hline $\begin{array}{l}\text { 4. Capacity Building for } \\
\text { Understanding Disaster } \\
\text { Risks }\end{array}$ & $\begin{array}{l}\text { Develop thematic DRR } \\
\text { Training packages }\end{array}$ & $\begin{array}{l}\text { Increased access to and use } \\
\text { of training opportunities }\end{array}$ & $\%$ & $\begin{array}{l}\text { Better capability to deliver } \\
\text { DRR interventions among } \\
\text { DRR implementing agencies }\end{array}$ \\
\hline
\end{tabular}

Core Indicator 4: A national multi-sectoral platform for disaster risk reduction is functioning

\section{Priority for Action 2:}

It identifies, assesses and monitors disaster risks and enhance early warning system (Table 2).

\section{Priority for Action 3:}

It uses knowledge, innovation and education to build a culture of safety and resilience at all levels (Table 3 ). Core Indicator 1: Relevant information on disasters is available and accessible at all levels, to all stakeholders (through networks, development of information sharing systems, etc.)

Core Indicator 2: School curricula, education material and relevant trainings include education and recovery concepts and practices

Core Indicator 3: Research methods and tools for multi- 
Table 2: SFDRR Priority of Action 2 - Strengthening disaster risk governance to manage disaster risk (UNISDR, 2015)

\begin{tabular}{|c|c|c|c|c|}
\hline Activity & Instrument & Indicator & $\begin{array}{l}\text { Unit of } \\
\text { Measure }\end{array}$ & Anticipated Outcome \\
\hline $\begin{array}{l}\text { 1.Establishment and Strengthening } \\
\text { of Institutions and Organizations }\end{array}$ & $\begin{array}{l}\text { Establish National DRR } \\
\text { Authority and its entities }\end{array}$ & $\begin{array}{l}\text { Increased nos. operation of } \\
\text { NDRRA and its entities }\end{array}$ & Number & $\begin{array}{l}\text { Operation of NDRR Authority } \\
\text { and its entities are improving }\end{array}$ \\
\hline $\begin{array}{l}\text { 2. Development of legal and } \\
\text { regulatory frameworks }\end{array}$ & $\begin{array}{l}\text { Prepare SOPs, guidelines } \\
\text { or desired regulations for } \\
\text { implementations of DRR }\end{array}$ & $\begin{array}{l}\text { Existence of SOPs, } \\
\text { Guidelines, and regulation } \\
\text { for implementations of } \\
\text { DRR interventions }\end{array}$ & Number & $\begin{array}{l}\text { DRR and Management Act } 2017 \\
\text { is functional and supportive for } \\
\text { implementation of DRR }\end{array}$ \\
\hline $\begin{array}{l}\text { 3. Capacity Building, Collaboration } \\
\text { and Partnership for Good } \\
\text { Governance in Disaster Risk } \\
\text { Reduction }\end{array}$ & $\begin{array}{l}\text { Establish inter- } \\
\text { organizational } \\
\text { collaboration and } \\
\text { partnership among } \\
\text { interrelated organizations } \\
\text { /institutions for Good } \\
\text { Governance }\end{array}$ & $\begin{array}{l}\text { Increased satisfaction of all } \\
\text { stakeholders on DRR } \\
\text { Governance }\end{array}$ & $\%$ & $\begin{array}{l}\text { DRR interventions are } \\
\text { delivering and satisfaction level } \\
\text { of all stakeholders are improving }\end{array}$ \\
\hline $\begin{array}{l}\text { 4. Ensuring Inclusive Governance in } \\
\text { Disaster Risk Reduction }\end{array}$ & $\begin{array}{l}\text { Adopt GESI Operational } \\
\text { Guideline published by } \\
\text { NPC, } 2013 \text { in all DRR } \\
\text { interventions }\end{array}$ & $\begin{array}{l}\text { Increased implementation } \\
\text { of GESI Operational } \\
\text { Guideline }\end{array}$ & $\%$ & $\begin{array}{l}\text { DRR interventions are getting } \\
\text { more inclusive and gender } \\
\text { friendly }\end{array}$ \\
\hline
\end{tabular}

Table 3: SFDRR Priority of Action 3 - Investing in disaster risk reduction for resilience (UNISDR, 2015)

\begin{tabular}{|c|c|c|c|c|}
\hline Activity & Instrument & Indicator & $\begin{array}{l}\text { Unit of } \\
\text { Measure }\end{array}$ & Anticipated Outcome \\
\hline $\begin{array}{l}\text { 1. Promoting Investments in } \\
\text { Building Disaster Resilience }\end{array}$ & $\begin{array}{l}\text { Implement the DRR \& } \\
\text { Management Act } 2017 \\
\text { including section on } \\
\text { investments }\end{array}$ & $\begin{array}{l}\text { Increased investment in } \\
\text { Building Disaster } \\
\text { Resilience }\end{array}$ & $\%$ & $\begin{array}{l}\text { Substantial increment in } \\
\text { investments in Building Disaster } \\
\text { Resilience }\end{array}$ \\
\hline $\begin{array}{l}\text { 2. Increasing Public Expenditure in } \\
\text { Disaster Risk Reduction }\end{array}$ & $\begin{array}{l}\text { Allocate exclusive budget } \\
\text { for DRR activities in all } \\
\text { development sector }\end{array}$ & $\begin{array}{l}\text { Increased public } \\
\text { expenditure in DRR } \\
\text { activities in all } \\
\text { development sector }\end{array}$ & $\%$ & $\begin{array}{l}\text { Substantial increment of public } \\
\text { expenditure in DRR activities }\end{array}$ \\
\hline $\begin{array}{l}\text { 3. Promoting Private Investment in } \\
\text { Disaster Risk Reduction }\end{array}$ & $\begin{array}{l}\text { Implement the DRR \& } \\
\text { Management Act } 2017 \\
\text { including section on Private } \\
\text { Sector }\end{array}$ & $\begin{array}{l}\text { Increased investment from } \\
\text { Private sector towards DRR }\end{array}$ & $\%$ & $\begin{array}{l}\text { Substantial increment in Private } \\
\text { sector investment in DRR sector }\end{array}$ \\
\hline $\begin{array}{l}\text { 4. Enhancing Disaster Resilience } \\
\text { Through Risk Sharing, Insurance } \\
\text { and Social Security }\end{array}$ & $\begin{array}{l}\text { Implement the GoN's } \\
\text { Corporate Social } \\
\text { Responsibility (CSR) Policy } \\
\text { effectively }\end{array}$ & $\begin{array}{l}\text { Increased CSR initiatives by } \\
\text { Commercial Banks and } \\
\text { Insurance Co. to enhance } \\
\text { disaster resilience }\end{array}$ & $\%$ & $\begin{array}{l}\text { Substantial increment of Private } \\
\text { Banks and Insurance Companies } \\
\text { in mobilizing funds towards } \\
\text { improving disaster resilience }\end{array}$ \\
\hline
\end{tabular}

risk assessments and cost benefit analysis are developed and strengthened

Core Indicator 4: Countrywide public awareness strategy exists to stimulate a culture of disaster resilience, with outreach to urban and rural communities

\section{Priority for Action 4:}

It reduces the underlying risk factors (Table 4):

Core Indicator 1: Disaster risk reduction is an integral objective of environment related policies and plans, including for land use natural resource management and adaptation to climate change

Core Indicator 2: Social development policies and plans are being implemented to reduce the vulnerability of populations most at risk

Core Indicator 3: Economic and productive sectorial policies and plans have been implemented to reduce the vulnerability of economic activities

Core Indicator 4: Planning and management of human settlements incorporate disaster risk reduction elements, including enforcement of building codes

Core Indicator 5: Disaster risk reduction measures are 
Table 4: SFDRR Priority Action 4 - Enhancing Disaster Preparedness for Effective Response and to 'Build Back Better' in Recovery, Rehabilitation and Reconstruction (UNISDR, 2015)

\begin{tabular}{|c|c|c|c|c|}
\hline Activity & Instrument & Indicator & $\begin{array}{l}\text { Unit of } \\
\text { Measure }\end{array}$ & Anticipated Outcome \\
\hline $\begin{array}{l}\text { 1. Strengthening Disaster } \\
\text { Preparedness for Effective } \\
\text { Response }\end{array}$ & $\begin{array}{l}\text { Conduct participatory Disaster } \\
\text { Preparedness (DP) Awareness } \\
\text { campaign at all level }\end{array}$ & $\begin{array}{l}\text { Increased understanding } \\
\text { among community } \\
\text { people for DP }\end{array}$ & $\%$ & $\begin{array}{l}\text { Alleviated response to DP from } \\
\text { community people }\end{array}$ \\
\hline $\begin{array}{l}\text { 2. Develop Multi-Hazard Early } \\
\text { Warning Systems for Disaster } \\
\text { Preparedness }\end{array}$ & $\begin{array}{l}\text { Conduct thematic participatory } \\
\text { Focused Group Trainings } \\
\text { (FGTs) of Community Leaders }\end{array}$ & $\begin{array}{l}\text { Increased nos. of } \\
\text { operational multi-hazard } \\
\text { EWS }\end{array}$ & $\%$ & $\begin{array}{l}\text { Alleviated response to timely } \\
\text { evacuation and other DP from } \\
\text { community people }\end{array}$ \\
\hline $\begin{array}{l}\text { 3. Strengthen Community Based } \\
\text { Disaster Preparedness for } \\
\text { Disaster resilience }\end{array}$ & $\begin{array}{l}\text { Conduct General Disaster } \\
\text { Awareness campaign }\end{array}$ & $\begin{array}{l}\text { Increased understanding } \\
\text { among community } \\
\text { people for DP }\end{array}$ & $\%$ & $\begin{array}{l}\text { Alleviated response to DP from } \\
\text { community people }\end{array}$ \\
\hline $\begin{array}{l}\text { 4. Strengthening Communication } \\
\text { \& Dissemination System for } \\
\text { Disaster Preparedness }\end{array}$ & $\begin{array}{l}\text { Develop an exclusive } w e b \\
\text { portal to disseminate DP } \\
\text { information }\end{array}$ & $\begin{array}{l}\text { Efficient dissemination } \\
\text { and community of DP } \\
\text { information }\end{array}$ & $\%$ & $\begin{array}{l}\text { Improved and timely DP } \\
\text { information to community } \\
\text { people }\end{array}$ \\
\hline $\begin{array}{l}\text { 5. Build Capacity on Search, } \\
\text { Rescue and Emergency Response }\end{array}$ & $\begin{array}{l}\text { Conduct thematic Focused } \\
\text { Group Trainings (FGTs) on } \\
\text { SRER to Community Leaders }\end{array}$ & $\begin{array}{l}\text { Improved SRER } \\
\text { operations }\end{array}$ & $\%$ & $\begin{array}{l}\text { Decreased nos. of deaths due to } \\
\text { Disasters }\end{array}$ \\
\hline $\begin{array}{l}\text { 6. Promote Recovery, } \\
\text { Rehabilitation and } \\
\text { Reconstruction (R3) for 'Build } \\
\text { Back Better' (B3) }\end{array}$ & $\begin{array}{l}\text { Conduct accurate } \\
\text { socioeconomic survey before } \\
\text { standard R3/B3 }\end{array}$ & $\begin{array}{l}\text { Increased Efficiency } \\
\text { during standard R3/B3 }\end{array}$ & $\%$ & $\begin{array}{l}\text { Timely delivery of standard } \\
\text { R3/B3 }\end{array}$ \\
\hline
\end{tabular}

integrated into post disaster recovery and rehabilitation processes

Core Indicator 6: Procedures are in place to assess the disaster risk impacts of major development projects, especially infrastructure

\section{Priority for Action 5:}

It strengthens disaster preparedness for effective response at all levels.

Core Indicator 1: Strong policy, technical and institutional capacities and mechanisms for disaster risk management, with a disaster risk reduction perspective are in place Core Indicator 2: Disaster preparedness plans and contingency plans are in place at all administrative levels, and regular training drills and rehearsals are held to test and develop disaster response programmes Core Indicator 3: Financial reserves and contingency mechanisms are in place to support effective response and recovery when required

Core Indicator 4: Procedures are in place to exchange relevant information during hazard events and disasters, and to undertake post-event reviews

\section{HIGHLIGHTS OF DRR AND MANAGEMENT ACT 2017 AND STRATEGIC ACTION PLAN}

Following the implementation of Hyogo Framework of Action 2005-2015 across the globe, the 3rd World Conference on DRR, held in Japan in March 2015, adopted Sendai Framework for Disaster Risk Reduction (SFDRR) for 20152030 (UNISDR, 2015) being endorsed by Nepal.

As an initiative towards implementation of SFDRR, the GoN under the leadership of MOHA, the DRR \& Management Act, 2017 has been declared which is under the process of promulgation. The Act is comprehensive and include provisions that would resolve majority of DRR issues as highlighted below:

- Guided by the Constitution of Nepal 2015

- DRR and Management Council headed by the Hon. Rt. Prime Minister

- Arrangement of powerful executive body - DRR and Management Authority lead by Secretary Level CEO with power to declare State of Emergency and approval to Foreigners mobilization during disasters

- Provision of formation of Expert Committee

- Authority dedicated to local DRR Committee

- Operation of National Emergency Operation System

- Provision of Volunteer mobilization

- Pre-disaster arrangement of Disaster Response Flying Squad Team

- Provision of Early Warning System

- Involvement of Civil Society and Private Sector in Disaster Management

- Define Roles, Responsibility and Authority of Security Authorities including mobilization of Army 
- Development of drrportal.gov.np

The MOHA in consultation with other stakeholders has developed National DRR policy and Strategic Action Plan 20172030. The prime Working Committee (WC) led by MOHA include representatives from the Prime Minister's Office, National Planning Commission, MOHA, MOFALD, MOUD, $\mathrm{MOH}, \mathrm{MOPE}$ and also included are none state organizations - I/NGOs, Donors, UNRCO, UNDP, NRCS, DP Net, AINTDGM, Private sectors/FNCCI while six thematic working groups (TWGs) are lead by their respective sectoral ministries. Guiding principle adopted for the formulation of the National DRR policy and Strategic Action Plan in line with SFDRR and Sustainable Development Goals (SDGs) are:

- Central focus on DRR

- Comprehensive understanding of disaster risks and underlying causes

- Integration of DRR activities across all relevant sectors

- Multi-hazard approach for reducing disaster risks

- Develop and expand multi-hazard Early Warning System

- Compliment relevant SDGs motto - no one left behind

As per strategic action plan vision, mission and goal in the national context has been set out:

Vision: Developing a Resilient nation through mitigating risks and adapting to changes; and contributing to Sustainable Development Goals

Mission: Reduce loss and damage by disasters to: individual, community and nation

Goals: 1). Reduce no. of death and number of affected population, and 2). Reduce the damage caused to lives, livelihood and assets

The central working committee and thematic working group has already initiated consultation meetings workshops at central (1 event), regional (2 regional events), and district level (7 district events) respectively as a preparation towards implementing 4 Priority of Actions underlined in SFDRR.

\section{CHALLENGES AND GAPS}

In the past, particularly in course of HFA implementation, Nepal experienced few fundamental several challenges and gaps. Based on semi-structured questionnaire assessment in key technical departments (state agencies) and own observation, few fundamental challenges and gaps that could be the root cause of weak effectiveness and sustainability of DRR interventions in Nepal has been analysed.

\section{Challenges}

First and fore-most fundamental challenge is posed by the implementation of Federal System of the Government. Accordingly, the formation of state government has already begun with ambitious development agenda without desired laws, rules and regulations, resources and above all lack of experience even for day to day work are extremely challenging. Under this situation besides these fundamental challenges, additional challenges on DRR interventions are inevitable as listed below.

1. Establishing appropriate institutional setups for DRR at all levels of Government

2. Mainstreaming DRR into development planning process at Federal, Provincial and Local levels

3. Establishing (including updating and customizing) and operating Disaster Information System at Federal, Provincial and Local levels

4. Implementation of DRR and Management Act 2017 without desired preparation would induct additional challenges as below:

a. Generation of huge financial resource in order to implement DRR interventions down to community level with focus on gender and equity concerns

b. Both intra and inter coordination among Executive Committee, National Disaster Risk Reduction Authority and Expert Committee as provisioned in the Act, given the failed past experience and the current structure is more complex

c. Inter coordination between central level NDRRA, Provincial and Local level DRR committees

d. Establishment and operation of multi-hazard early warning system particularly at Provincial and Local level DRR committees due to absolute lack of personnel with desired technical expertise

e. Establishment and operation of Emergency Operation Centers (EOCs) including high tech Search and Rescue (SAR) particularly at Provincial and Local level DRR committees

f. Consistency in formulation and implementation of National DRR Policy and Strategic Action Plan across the country

g. Result based monitoring and evaluation and reporting as per the established indicators at National and global levels in line with Sendai Framework of Disaster Risk Reduction and Sustainable Development Goals (Table 5)

\section{Gaps}

There are fundamental and common gaps in majority of the state agencies as underlies.

\section{Financial Resource Gap}

There is a huge gap in the allocated public budget as against the needed budget to address the ever increasing natural hazards manifestations which is exacerbated by climate change across the country in recent years. It is learnt that allocated 
annual budget is in general 'sprinkled' over the impacted area by natural hazards particularly to address recurrent disasters such as landslides, floods, in such a way to cover a maximum area irrespective of cost estimate as per desired design. This practice of sprinkling annual budget for the sake of wider coverage is common among majority of the departments. Watershed management is limited to small catchments and potential landslides are ignored due to financial resource gap. Similarly, desired mitigation works are ignored by other infrastructure development works such as roads, irrigation, hydropower, transmission line and telecommunication tower networks among others.

\section{Human Resource Gap}

Human resource has been one of the key factors for delivering the effective services including DRR. Inadequate human resource has been a common issue in the technical departments. Staffs with adequate DRR knowledge and capacity to deliver are minimal. Lack of DRR trained staffs for field works, necessary survey for mitigation design, training of trainers, supervision to mitigation works implemented by user groups are evident. To cover all these works by available staffs is taking longer time. Often times there has been geological, environmental and social issues while implementing DRR interventions. But in general, there is hardly any sociologist or environment specialist to address the issues. This human resource gap is impacting DRR interventions adversely.

\section{Capacity Building Gap}

It is understood that there is no any institutional arrangement for capacity building of staffs in any of the technical departments except that staffs are given some opportunity for trainings largely on Ad hoc basis irrespective of needs. As mentioned above often times staffs are not able to deliver desired service due to lack of DRR knowledge and new technical developments. This gap on capacity building do have adverse impacts on quality and sustainability of DRR interventions.

\section{Planning Gap}

It has been customary to prepare Annual Programme of each department upon allocation of public budget i.e., only after the fiscal budget announcement irrespective of the scientific/technical requirements depending upon the depth and dimension of the potential natural hazards. Further this the Annual Programme is prepared in an 'Ad hoc basis' without much consultations and DRR needs assessments. On the other hand, such programmes are politically influenced. DRR periodic plans were prepared in several districts with the inputs from donor supplied Consultants but then hardly implemented due to gaps mentioned above. The practice of long term preparing integrated DRR plan based on consultations with local community as well as technical and socio-economic assessments that is effective and sustainable is far from practice yet.

\section{Research and Development Gap}

In this ever-changing world including the climate change, which has high impacts on DRR has got to be changing too. To understand and to cope with such natural, technological, socioeconomic and environmental change, it is essential to have research and development in DRR interventions. But there is no any such provision in any of the technical departments assessed and this is an imminent gap. This gap has to be fulfilled for effective and sustainable DRR.

\section{THEORY OF CHANGE}

A theory of change (Fig. 6) has been envisioned, aimed at improving the effectiveness and sustainability of to be implemented DRR interventions as per Priority of Actions identified by the GoN. Corresponding instruments, indicators, unit of measure and anticipated outcome of DRR activities in line with SFDRR has been devised. A model Results Framework for future monitoring and reporting for four Priority of Action 2030 at National and global level, if desired, has also been developed.

Table 5: Model Results Framework for Monitoring, Evaluation and Reporting

\begin{tabular}{|c|c|c|c|c|c|c|c|c|c|c|c|c|}
\hline \multirow{2}{*}{ 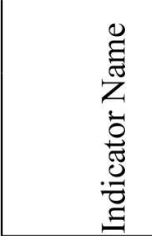 } & \multirow{2}{*}{ 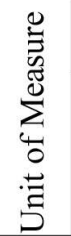 } & \multirow[b]{2}{*}{ 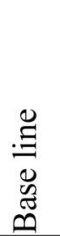 } & \multicolumn{6}{|c|}{ Cumulative Target Values } & \multirow[b]{2}{*}{ 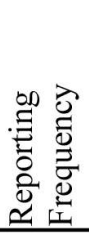 } & \multirow[b]{2}{*}{ 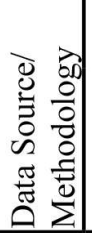 } & \multirow[b]{2}{*}{ 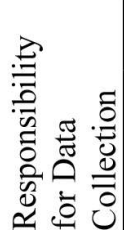 } & \multirow[b]{2}{*}{ 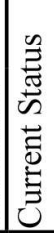 } \\
\hline & & & $\vec{z} \underset{\sim}{\infty}$ & $\stackrel{2}{2} \stackrel{\vec{\lambda}}{\vec{i}}$ & ટ્રે & 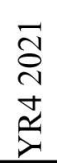 & ڤ્ટે & 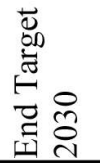 & & & & \\
\hline \multicolumn{13}{|l|}{ Indicator 1} \\
\hline \multicolumn{13}{|l|}{ Indicator 2} \\
\hline \begin{tabular}{|l} 
Indicator 3 \\
on
\end{tabular} & & & & & & & & & & & & \\
\hline
\end{tabular}




\section{GOAL}

1. Reduce no. of death and no. of affected population

2. Reduce the damage caused to lives, livelihood and asset

\section{End-line Scenario 2030}

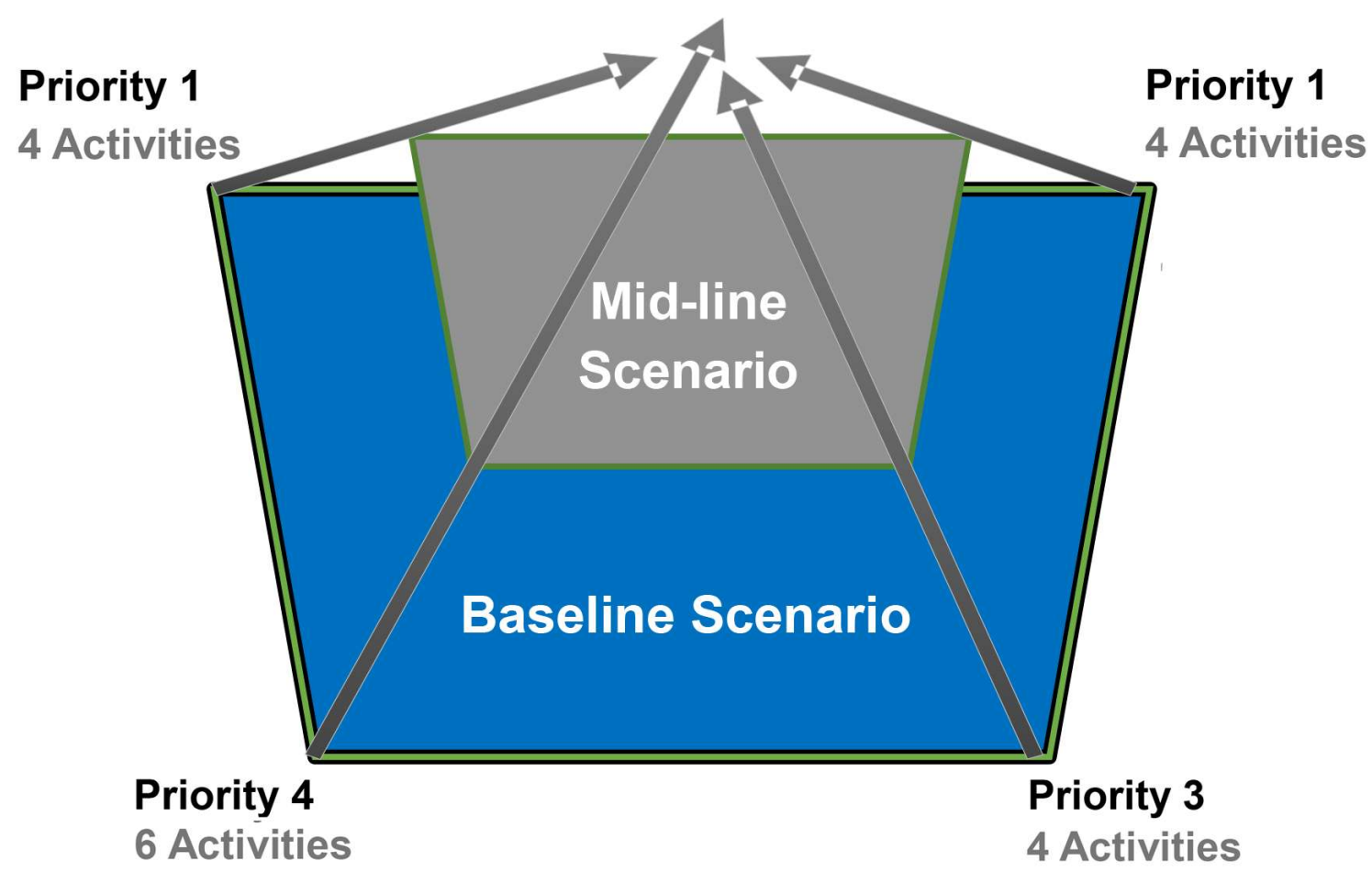

Fig 6: Theory of change

For regular monitoring and reporting the model Results Framework (Table 5) for each SFDRR Priority of Action can be used.

\section{CONCLUSIONS}

Qualitative analysis of Core Indicators of 5 HFA Priority for Actions scored on an average 3 (Institutional commitment was attained but achievements are neither comprehensive nor substantial) out of 5 and in terms of effectiveness and sustainability also the score is 3 (moderately satisfactory) out of 5. However, the systematic monitoring, evaluation and reporting to national and/or global agencies was lacking. With this as a key learning from HFA implementation, Nepal may initiate a systematic monitoring, evaluation and reporting of ongoing 4 SFDRR Priority of Action to desired national and global agencies using the envisioned theory of chance and the proposed Results Framework. In doing so it is expected to improve overall performance of DRR interventions being implemented in Nepal.

\section{ACKNOWLEDGEMENTS}

This paper is the result of self motivation. However, the inspiration from the team of 18th Executive Board of Nepal Geological Society lead by the President Kabi Raj Paudyal is much appreciated for preparation of this paper. 


\section{REFERENCES}

National HFA Monitor Update Report, 2015, Ministry of Home Affairs, Published by Prevention Web, 2015, 65p. http//www.preventionweb.nef/English/hygo/progress/re ports

National Planning Commission, July 2013, National Monitoring and Evaluation Guidelines. Kathmandu: National Planning Commission, Government of Nepal, 99p.

Tuladhar, R.M., 2015, Significance of Management Response to Evaluation towards promotion of National Evaluation
Capacities in Nepal, In Forth International Conference on National Evaluation Capacities (NEC) NEC Proceedings, Bangkok, Thailand, 2015, pp. 103-110.

Third United Nations World Conference on Disaster Risk Reduction, 14-18 March, 2015, Proceedings, 169p.

UNISDR, 2015, Sendai Framework for Disaster Risk Reduction, 2015-2030, United Nations Office for Disaster Risk Reduction (UNDRR), 32p.

https://www.unisdr.org/we/inform/publications/43291 